\title{
Koordinerende praksisveileder på sykehus gir mer fornøyde studenter
}

\author{
$\AA$ fristille en sykepleier som kunne koordinere praksisveilederne og være bindeledd til \\ lærestedet, ga tryggere rammer og økt læringsutbytte for studentene.
}

\section{Forfattere}

\author{
Jarle Henriksen \\ Avdelingsleder \\ Kirurgisk avdeling for barn, OUS, Rikshospitalet

\section{Kathrine Espeland} \\ Universitetslektor \\ Institutt for sykepleie, OsloMet - storbyuniversitetet \\ Elisabeth Blasko \\ Koordinerende praksisveileder \\ Kirurgisk avdeling for barn, OUS, Rikshospitalet
}

\section{Nøkkelord}

Kvalitet Praksisstudie Veiledning Organisering

\section{HOVEDBUDSKAP}

Et godt samarbeid mellom høgskole og praksisfeltet er grunnleggende for kvaliteten på praksisstudiet. Spesialisthelsetjenesten er medansvarlig for utdanning av helsepersonell, og det er avgjørende at ledere tar ansvar ved å sette av ressurser og tilrettelegge for gode praksisperioder.

Implementering av en rolle som koordinerende praksisveileder bidrar til å heve kvaliteten på praksisstudiene. Det er viktig å ha systemer som sikrer god oppfølgning og veiledning, uavhengig av person.

Etter endt praksisperiode uttalte en student følgende: «Trygge rammer rundt praksisperioden gir godt grunnlag for læring i praksis!»

Denne artikkelen har bakgrunn i et prosjekt hvor det ble prøvd ut en modell for å heve kvaliteten på bachelorstudentenes kliniske studier. Modellen innebærer i korthet at en sykepleier får et overordnet ansvar for å koordinere praksis. Prosjektet var et samarbeid mellom Oslo universitetssykehus (OUS) og Høgskolen i Oslo og Akershus (HiOA), nå Oslomet - storbyuniversitetet.

\section{Bakgrunn}

Elementer som fremmer læring og økt kvalitet i de kliniske studiene, er godt beskrevet i litteraturen. Ulike praksismodeller er prøvd ut, og mange praksisplasser har allerede gode rutiner og god struktur $(2-5,13)$. 
Vår avdeling, Kirurgisk avdeling for barn (KAB), er inndelt i fire seksjoner (sengeposter). Vår erfaring var at mye fungerte bra, men at tilbudet til sykepleierstudentene var ulikt på de forskjellige seksjonene. Med utgangspunktet i et ønske om et likeverdig veiledningstilbud for studentene, og et tettere samarbeid med høgskolen, gjennomførte vi fra 2015 til 2016 et samarbeidsprosjekt med HiOA.

Vi hadde mange mål for prosjektet. Blant annet ønsket vi at mottak, informasjon og oppfølgning underveis av studentene skulle standardiseres. I forkant av praksisperioden skulle studentene få grundig informasjon om relevante læresituasjoner, diagnoser, medikamenter og prosedyrer ved seksjonene.

Kontaktsykepleierne skulle følges bedre opp, og vi ønsket også at antallet kontaktsykepleiere skulle reduseres. Sykepleiere med veiledningsansvar skulle få hevet kompetansen, og seksjonens fagutviklingssykepleiere skulle få redusert sine arbeidsoppgaver.

\section{Ansvar for utdanning}

Det er utdanningsinstitusjonenes styrer som utarbeider retningslinjer og er ansvarlige for tilrettelegging og gjennomføring av praksisstudiene (6). Sykepleieledere på sengepostene har et løpende ansvar for å prioritere utdanning i en hektisk arbeidshverdag. Ledelse av praksis er nødvendig for å legge til rette for gode praksisperioder for fremtidige kollegaer.

Gode praksisplasser kjennetegnes av tydelig planer og mål for praksisstudiet. Det må være sammenheng mellom undervisningen $\mathrm{i}$ høgskolen og hva studenten møter i klinikken. Formelle samarbeidsarenaer mellom høgskole og praksisfelt er nødvendige for å redusere gapet mellom teori og praksis.

Studentene er tjent med klare og tydelig læringsutbytter og at forventninger kommuniseres før nye praksisperioder starter. Veilederne bør ha veilederkompetanse og være motivert for å ha studenter $(1,7,17)$.

\section{三 «Gode relasjoner mellom studenter og veiledere gir studentene tro på egne ressurser.»}

Praksisstedet har en stor del av veiledningsansvaret for sykepleierstudentene. Gode relasjoner mellom studenter og veiledere gir studentene tro på egne ressurser og skaper tillit i veiledningsforholdet. Dette er viktig for læringsutbyttet. Læring fremmes av at studentene opplever trygge rammer, mestring, kontroll og motivasjon.

En god veileder er bevisst egen atferd, tilpasser veiledningen til den enkelte student, og reflekterer over egen tilnærming og hvordan denne påvirker studenten. Samspillet forutsetter at praksisstedet har motiverte og engasjerte kontaktsykepleiere og veiledere $(8,9)$. 
Høgskolen har et stort ansvar for å skaffe alle studenter gode muligheter for kliniske studier (6). Høgskolen har et stort antall studenter og er avhengig av et godt samarbeid i alle ledd. Høgskolelektor må følge opp studentene i tett samarbeid med praksisfeltet. Det er inspirerende og motiverende for alle involverte når et slikt samarbeid fungerer optimalt til studentenes beste og vi ser at de oppnår den kompetansen som er forventet etter en praksisperiode.

\section{Prosjektplan}

Avdelingen gjennomførte i forkant av prosjektet gruppeintervju av lederne og fagutviklingssykepleiere ved de fire seksjonene. Det var fagutviklingssykepleierne som inntil da hadde hatt hovedansvaret for oppfølgning av sykepleierstudentene. Resultatet av intervjuene dannet utgangspunktet for de arbeidsoppgavene som ble lagt til koordinerende praksisveileder (KPV), heretter kalt KPV funksjonsområde.

$\AA$ fristille ansatte innenfor de rammene som en sengepost har, er utfordrende. For å få satt av tid til kompetanseheving for KPV og få planlagt og gjennomført prosjektet var det avgjørende å få tatt dem ut av ordinær drift. Til dette ble det søkt om samarbeidsmidler med HiOA. Midlene ble innvilget, og samarbeid med høgskolelektor opprettet.

Det ble lyst ut prosjektstillinger for KPV, som ble finansiert av samarbeidsmidlene. Fire sykepleiere med lang klinisk erfaring ble rekruttert, og de fikk avsatt 20 prosent av sin stilling til å delta i prosjektet.

\section{«Å fristille ansatte innenfor de rammene som en sengepost har, er utfordrende.»}

En av disse fikk i tillegg et overordnet ansvar for oppfølgning av gruppen og innkalling til og gjennomføring av prosjektmøter. Prosjektet omfattet fire praksisperioder med studenter fra høsten 2015 og frem til sommeren 2016. Trettito studenter var ved seksjonene i prosjektperioden.

For å kunne evaluere og revidere det skriftlige materiellet som ble utarbeidet, samt arbeidsoppgavene som KPV skulle ivareta, ble det utarbeidet et spørreskjema, som ble gitt til studenter og kontaktsykepleiere etter hver praksisperiode. Noen av tilbakemeldingene fra spørreundersøkelsen er gjengitt i denne artikkelen.

Mot slutten av prosjektet ble det gjennomført et fokusgruppeintervju med KPV-ene. Tilbakemeldingene fra spørreundersøkelsene, lederne og fagutviklingssykepleierne var så positive at avdelingen valgte å innføre KPV som en permanent ordning i avdelingen fra høsten 2016.

\section{Vår modell}

Vi kaller vår modell KAB-modellen. Modellen forutsetter at en sykepleier ved hver seksjon får avsatt 20 prosent av sin stilling som KPV. Mange titler benyttes på sykepleiere med ulike ansvar for studenter i praksis:

hovedveileder, studentansvarlig sykepleier, studentkontakt, praksiskoordinator, veileder og så videre. Vi mener at KPV er mest dekkende, da arbeidsoppgavene både er koordinering og veiledning. 
For KPV har vi utarbeidet en egen funksjonsbeskrivelse med tilhørende spesifisering av arbeidsoppgaver og diverse maler til støtte for selve utførelsen. Det er seksjonslederens ansvar å følge opp KPV - både at vedkommende utfører oppgavene som er tillagt funksjonen, og at det legges til rette for at KPV får muligheten til å øke egen veilederkompetanse.

Det er utarbeidet eget informasjonsmateriell med oversikt over læresituasjoner og funksjons- og arbeidsbeskrivelser for kontaktsykepleiere og studenter. Vi ser at vi har iverksatt mange av de anbefalte tiltakene fra Universitets- og høgskolerådets rapport Kvalitet i praksisstudiene i helseog sosialfaglig høyere utdanning (1).

Rapporten påpeker viktigheten av faste planer for gjennomføringen av veiledningsperioden. Planer gjør at kvaliteten opprettholdes selv om personen som ivaretar oppgavene, skiftes ut.

\section{Gjennomføring}

Modellen vår forutsetter at skriftlig materiell og planer utarbeides før vi tar imot studentene. Først avklarte vi hvilke oppgaver KPV skulle ha. Dernest må det utarbeides en funksjonsbeskrivelse og en konkretisering av arbeidsoppgavene. Funksjonsbeskrivelsen vår er tilgjengelig for alle i sykehusets interne kvalitetssystem.

I spesialisthelsetjenesten har vi til tider mye utskifting av ulike årsaker. Det å ha utarbeidet en funksjonsbeskrivelse gjør at en raskt kan erstatte KPV ved lengre sykefravær eller permisjoner.

Vår erfaring er at oppfølgningen av studentene blir dårligere når KPV ikke er til stede ukentlig. Vi har utarbeidet en tidsakse for når hvilke oppgaver skal gjennomføres (se figur 1). Dette sikrer lik gjennomføring av periodene - uavhengig av praksisplass.

Figur 1: Forløp praksisperiode

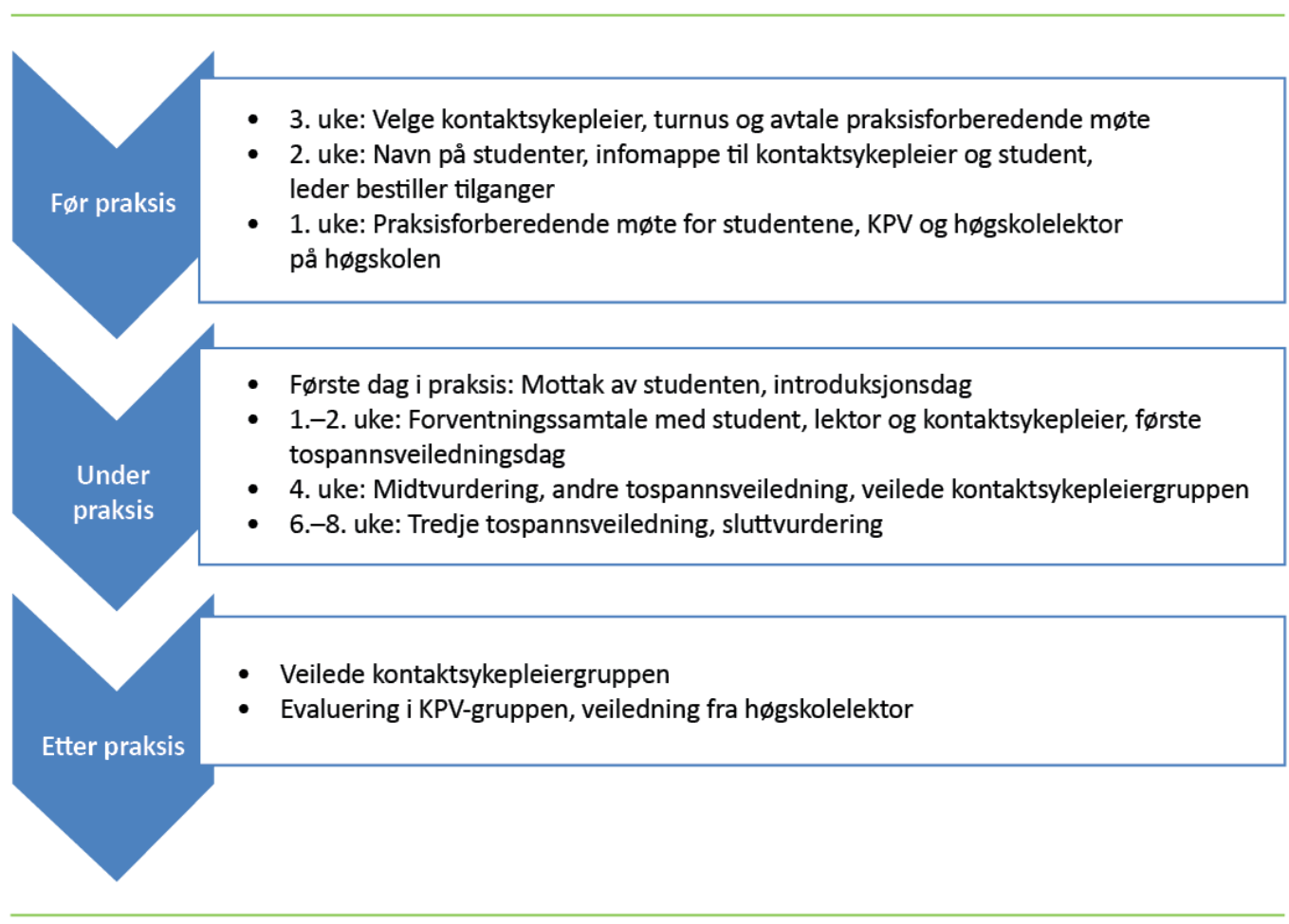


Det er avgjørende å rekruttere rett person til å ivareta rollen som KPV. Vi har søkt etter dem som har god erfaring fra praksisplassen, og som er trygge i rollen som sykepleier med den aktuelle pasientgruppen. Personen må like å veilede og være faglig engasjert. En av KPV-ene uttalte under fokusgruppeintervjuet mot slutten av prosjektperioden:

«Jeg har alltid likt å jobbe med studenter, jeg tok imot dem, jeg hadde litt ekstra tid med studentene. Så når den stillingen ble utlyst, så var det liksom: Der er stillingen min!»

Vi har vært opptatt av at vedkommende skulle ha et ønske om å tilegne seg mer formell veiledningskompetanse. I prosjektperioden og etter at ordningen med koordinerende praksisveileder ble gjort varig, har alle våre KPV-er gjennomført et 20 studiepoengs studieprogram i veiledning. Alle kontaktsykepleierne skal ha et tre dagers kontaktsykepleierkurs i regi av HiOA.

\section{Læresituasjoner}

For studentene ble det i forkant av prosjektet utarbeidet diverse skriftlig materiell. Dette materiellet inneholder en oversikt over læresituasjoner ved avdelingen som helhet og for den enkelte seksjon. I tillegg er det utarbeidet en oversikt over sykepleiernes oppgaver, pasientdiagnoser, medikamenter, daglige rutiner og annen praktisk informasjon ved seksjonene.

Vi var spesielt opptatt av at læringsutbyttene fra høgskolen skulle henge sammen med de læresituasjonene som praksis kunne tilby. Ved at praksisstedet identifiserer læresituasjoner, blir det også tydeligere for høgskolen hva som er sentralt i praksis.

Før praksisperioden kan studentene sette seg inn i hva som forventes av dem, og hva praksisplassen kan tilby av læresituasjoner. Det kan skape trygghet, raskere læring og bedre læringsutbytte $(1,10)$.

Studentene kan også bruke oversikten over læresituasjonene som en sjekkliste underveis i praksisperioden. Oversikten gir både kontaktsykepleier, høgskolelektor og KPV en god oversikt over hva studenten har gjennomgått og erfart.

\section{Veiledningskompetanse}

Underveis i prosjektperioden så vi at KPV kunne bruke mer av sin avsatte tid til å følge opp studentene på seksjonen. Det ble bestemt å innføre faste dager hvor KPV står for veiledning av studentene. Maler for veiledningen ble utarbeidet for å sikre likt innhold i og gjennomføring av disse dagene.

Studentene har fire-fem oppsatte veiledningsdager per praksisperiode. Dagene har tema som er relevante i en kirurgisk praksis og står i forhold til læringsutbyttene. Dagene skal gjennomføres etter tospannsmodellen, som innebærer veiledning i par (2). 
En annen oppgave som vi valgte å tillegge KPV, var tettere oppfølgning av kontaktsykepleierne. For å sikre dette skal KPV gjennomføre en-to planlagte veiledningssamtaler med kontaktsykepleierne i gruppe. Til disse samlingene er det utarbeidet relevante spørsmål som kan være nyttige for å strukturere samtalene. Ved at vi har tillagt KPV veiledningsoppgaver for både studentene og kontaktsykepleierne, mener vi at formell veiledningskompetanse hos KPV er viktig.

\section{Gjensidige forventninger}

Kontaktsykepleieren har hovedansvaret for veiledningen av studentene, og det forventes at studentene følger hans/hennes turnus. Det er utarbeidet en oversikt over hvilke arbeidsoppgaver som det forventes at kontaktsykepleierne ivaretar.

Vi har erfart at det er viktig med en tydelig avklaring av hvem som har hovedansvaret for hvilke oppgaver knyttet til oppfølgningen av studentene. Ved å avklare roller reduseres frustrasjon og dobbeltarbeid, og en slipper å være usikker på om noe er gjennomført eller fulgt opp.

For å bedre samarbeidet mellom høgskolen og praksis ble det utarbeidet en oversikt over gjensidige forventninger i løpet av praksisperiodene. Vi ser at dette er viktig når seksjonene får en ny høgskolelektor som skal følge opp studentene. Viktige punkter å avklare er tid for forventnings- og vurderingssamtaler, praksisforberedende møte og samarbeidsmøter med høgskolelektor.

\section{三 «For begge parter er forutsigbarhet og muligheten til å planlegge avgjørende.»}

For begge parter er forutsigbarhet og muligheten til å planlegge avgjørende. I samarbeidsmøtene mellom KPV og høgskolelektor har høgskolelektor i tillegg muligheten til å veilede KPV med sin pedagogiske kunnskap og erfaringer. Dette er spesielt nyttig i utfordrende studentsituasjoner.

Det er en forventning at KPV må gjøre seg kjent med høgskolesystemet, knytte kontakter på høgskolen og gjøre seg kjent med læringsutbytter og programplaner.

Materiellet og malene utgjør vår «verktøykasse» for ivaretakelsen av studentene. Alt er samlet i en egen perm (se figur 2), som er lett tilgjengelig på seksjonene. KPV har ansvar for oppdatering av alle dokumentene i samarbeid med høgskolelektor og seksjonens ledelse. 
Figur 2: Innhold i praksispermen

Koordinerende praksisveileder

- Funksjonsbeskrivelse

- Tidsakse

- Maler veiledningsdager

- Veiledning kontaktspl.

\section{Student}

- Praktisk informasjon

- Læringsmuligheter

- Diagnoser

- Medikamenter m.m.
Kontaktsykepleier

- Informasjon om utdanningen

- Informasjon om student

\section{Høgskolelektor}

- Informasjon om og fra høgskolen

- Forventninger til høgskolelektor fra praksis

\section{KVPs rolle}

Høgskolelektor tar kontakt og gjør avtaler med KPV et par uker før oppstart av en ny praksisperiode. KPV må i forkant ha avklart kontaktsykepleiere for de nye studentene og hvilken turnus de skal følge. Kontaktsykepleierne bør ikke ha for mange nattevakter, ferier, friuker og så videre i perioden studentene er til stede.

Høgskolelektoren tar ansvar for og arrangerer et felles møte mellom studentene og KPV før oppstart. Vi har bestemt at KPV skal delta på det praksisforberedende møtet på høgskolen.

Det har gitt svært gode tilbakemeldinger fra både studenter og lektor. Her får studentene både muntlig og skriftlig informasjon om praksisplassen, og kontakt mellom student og praksis opprettes. Noen studenter uttalte i spørreundersøkelsen etter endt praksisperiode:

«Det praksisforberedende møtet var nyttig fordi en fikk sett et ansikt og en følte seg ikke så ny og alene som student første dagen.»

«Informasjonsmappen var et nyttig verktøy som jeg kunne forbedre meg med og jeg visste mer hva som var i vente.»

Studentene har alltid mange spørsmål før de begynner. Ved at de møter noen av de ansvarlige veilederne og får denne informasjon i forkant av praksis, opplever studentene trygghet og forutsigbarhet og kan raskere ta til seg læring $(8,9,14)$. 
For å kunne gi god og individuell veiledning er det viktig å ha kunnskap om studentenes ståsted og læreforutsetninger (15). Under prosjektet ble det utviklet et skjema som studentene skulle fylle ut før praksisperioden. Der spørres de om tidligere praksisplasser i studiet, arbeidserfaring, eventuell erfaring med barn, bacheloroppgavens tema og om de har noen spesielle behov. Denne informasjonen deles med veilederne i forkant av praksisperioden.

\section{Løpende dialog}

Første dag i praksis er lik for alle studentene ved avdelingens fire seksjoner. Studentene blir tatt imot på seksjonen av KPV og får en omvisning. Senere på dagen får de fellesundervisning i HLR, brannvern, personvern og informasjonssikkerhet og kommunikasjon med barn og foreldre.

Underveis i praksisperioden har KPV, kontaktsykepleier og lektor løpende dialog om studentenes progresjon. Såfremt det er mulig, deltar KPV på forventningssamtaler og midt- og sluttvurderinger. Kontaktsykepleier er primært den som skal delta, sammen med høgskolens veileder.

Vår erfaring er at det er svært viktig at flere veileder og ser studenten. Ved utfordringer som oppstår i praksisperioden, er det flere som kan bidra til å vurdere og løse situasjonen. Samarbeidet mellom alle de involverte bidrar til at studenten får en god læringsprosess.

\section{«Vår erfaring er at det er svært viktig at flere veileder og ser studenten.»}

KPV skal gjennomføre fire-fem forhåndsavtalte veiledningsdager med studentene. Studentene og KPV velger temaet for veiledningen sammen. Temaet velges ut fra hvilke læresituasjoner som er aktuelle ved seksjonen, samt studentenes behov for veiledning og læringsutbytter.

KPV justerer sin veilederstil basert på flere faktorer: tema, pasientenes behov, samarbeidet mellom studentene og studentenes individuelle nivå. På tospannsdager er det viktig å vektlegge samarbeidslæring, det vil si at studentene bruker hverandre som ressurs og samarbeider aktivt for å utøve god sykepleie, oppleve mestring og nå felles mål $(2,11)$.

På slutten av en veiledningsdag gjennomfører KPV etterveiledning med studentene. Vår erfaring med faste veiledningsdager i par er at studentene opplever disse som svært verdifulle. Studentene uttalte blant annet følgende etter en endt praksisperiode:

«Fint med en hel dag til ett fokusområde. Prøving og feiling.»

«Vi fikk god tid på oss til å tenke og reflektere over det vi gjorde.»

\section{Kontaktsykepleiers rolle}

I tillegg til ansvaret for studentene har KVP også et medansvar for å følge opp kontaktsykepleierne ved seksjonen. Hver seksjon har en gruppe med kontaktsykepleiere (rundt seks-åtte sykepleiere) som bytter på å ha ansvar for studenter. Både litteratur og erfaring viser at det kan være mye frustrasjon knyttet til rollen som kontaktsykepleier (12). Våre spørreundersøkelser avdekket det samme. 
I tillegg til de formelle veiledningssamtalene med kontaktsykepleiergruppen gir KPV individuell veiledning og bistår i vanskelige og krevende studentsituasjoner. Samarbeidet med høgskolelektoren er viktig her. For at praksisperioden skal bli vellykket, er det vesentlig at kontaktsykepleierne får støtte, følges opp og blir sett (12).

Fra et utgangspunkt hvor ledere slet med å finne og motivere sykepleiere til å være kontaktsykepleiere, har vi nå venteliste for dem som ønsker å bli en del av seksjonens kontaktsykepleiergruppe.

\section{¿ «For at praksisperioden skal bli vellykket, er det vesentlig at kontaktsykepleierne får støtte, følges opp og blir sett.»}

I løpet av prosjektet ble det etablert en viktig samarbeidsarena mellom skole og praksis. Det innkalles nå til regelmessige møter hver tredje uke mellom høgskolelektor og KPV-er. På disse møtene diskuteres erfaringer og utfordringer knyttet til rollen som KPV.

Rollen er fortsatt ny, og en trenger tid til å justere struktur og arbeidsoppgaver etter hvert som vi skaffer oss erfaring og får tilbakemeldinger fra spørreundersøkelsene. Høgskolelektor kan gi råd og innspill, og møtet er blitt en viktig arena for opplæring av nye KPV-er.

Gruppen øker engasjementet og bevisstheten rundt utdanningsansvaret ved at de har deltatt på flere kongresser og seminarer med ulike postere. På denne måten har vi fått videreformidlet kunnskap og erfaringer fra prosjektet.

\section{Konklusjon}

Vårt prosjekt viser at et godt samarbeid mellom høgskole og praksisfelt er grunnleggende for kvaliteten på praksisstudiet. Det at vi fysisk møtes, blir kjent med hverandre og etablerer relasjoner, gjør at vi blir trygge på hverandre.

Gjennom samarbeidsprosjekter kommer høgskole og praksis tettere på hverandre, og resultatet er at vi ikke ser på hverandre som «oss og dem», men som et «vi». Vi er likestilt, og vi står sammen om å utdanne fremtidens sykepleiere. Vi erfarte at noe av gapet mellom teori og praksis minket. Forventningene til det teoretiske og praktiske grunnlaget som studentene har med seg fra høgskolen, er nå mer realistiske.

Dette er i tråd med NSFs politiske plattform for sykepleierutdanning 20172020. Her er et av satsingsområdene å styrke praksisstudiene, med en forventning om at det blir satt fokus på de samme områdene som vi har jobbet med, i den fremtidige sykepleierutdanningen (16).

Et hovedansvar for spesialisthelsetjenesten er å utdanne helsepersonell. Det krever ressurser, prioritering og tilrettelegging for å kunne tilby kvalitativt gode praksisplasser. Ved å implementere en modell som prioriterer ressurser inn i en sentral funksjon ved praksisplassene, har vi etablert et læringsmiljø hvor studenter, veiledere og høgskolen opplever å lykkes. 
Vi må lage systemer som ikke gjør oss sårbare for endringer. Sykepleiere i dag blir ikke værende ved den samme arbeidsplassen hele yrkeskarrieren. Mye utskifting utfordrer kvaliteten på mange områder. Vi må sikre at kvaliteten på praksisstudiene opprettholdes og ikke er basert på enkeltpersoner og deres personlige kompetanse.

\section{Referanser}

1. Universitets- og høgskolerådet. Kvalitet i praksisstudiene i helse- og sosialfaglig høyere utdanning: praksisprosjektet. Oslo: Universitets- og høgskolerådet; 2016. Tilgjengelig fra: https://www.regjeringen.no/contentassets/86921ebe6f4c45d9a2f67fda3e6eae08/praksisprosjektetsluttrapport.pdf (nedlastet 20.02.2018).

2. Drange BB. Utprøving av tospann som veiledningsmodell. Uniped.

2013;36(3). Tilgjengelig fra: https://www.idunn.no/uniped/2013/03/utproeving_av_tospann_som_veiledningsmodell (nedlastet 20.02.2018).

3. Alexandersen I, Nakrem S, Mathisen M. En ny praksismodell i sykepleierutdanningen for fremtidens behov? Vård i Norden. 2014;34(2):49.

4. Halse K, Steen I, Notevarp JO, Leegaard M. Studenttett post funker for de fleste. Sykepleien. 2016;(2):50-3. Tilgjengelig fra: https://sykepleien.no/forskning/2016/01/studenttett-post (nedlastet 20.02.2018).

5. $\quad$ Tandberg BS, Kristensen F. Bedre samarbeid om praksis. Sykepleien. 2014;(1):48-51. Tilgjengelig fra: https://sykepleien.no/forskning/2014/01/bedre-samarbeid-om-praksis (nedlastet 20.02.2018).

6. Kunnskapsdepartementet. Rammeplan for sykepleierutdanningen.

Oslo; 2008. Tilgjengelig fra:

https://www.regjeringen.no/globalassets/upload/kd/vedlegg/uh/rammeplaner/helse/rammeplan_sykepleierutdanning_08.pdf (nedlastet 08.01.2018).

7. Hauge KW, et al. Kvalitet i praksisstudier i sykepleier- og

vernepleierutdanning. Nordisk tidsskrift for helseforskning. 2016;12(1).

Tilgjengelig fra:

http://septentrio.uit.no/index.php/helseforsk/article/view/3772 (nedlastet 20.02.2018).

8. Haugan G, Aigeltinger E, Sørlie V. Relasjonen til veileder betyr mye for sykepleierstudenter i sykehuspraksis. Sykepleien Forskning. 2012;7(2):153-8. Tilgjengelig fra: https://sykepleien.no/forskning/2012/06/relasjonen-til-veileder-betyr-myesykepleierstudenter-i-sykehuspraksis (nedlastet 20.02.2018).

9. Vistnes K, Ask KL, Byklum HK, Øhr VG. Samarbeid gir god praksis. Sykepleien. 2013;13:52-4. Tilgjengelig fra: https://sykepleien.no/forskning/2013/11/samarbeid-gir-god-praksis (nedlastet 20.02.2018). 
10. Haddeland K, Söderhamn U. Sykepleierstudenters opplevelse av veiledningssituasjoner med sykepleiere i sykehuspraksis. Nordisk sygeplejeforskning. 2013;3(1):18-32.

11. Haugan G, Sørensen AH. The importance of dialogue in student nurses' clinical education. Nurse Educ Today. 2012;32(4):438-42.

12. Aigeltinger E, Haugan G, Sørlie V. Utfordringer med å veilede sykepleierstudenter i praksisstudier. Sykepleien Forskning. 2012;7(2):1606. Tilgjengelig fra: https://sykepleien.no/forskning/2012/06/utfordringermed-veilede-sykepleierstudenter-i-praksisstudier (nedlastet 08.01.2018).

13. Kårstein A, Caspersen J. Praksis i helse- og sosialfagutdanningene: en litteraturgjennomgang. Oslo: Nordisk institutt for studier av innovasjon, forskning og utdanning; 2016. NIFU-rapport 2014:16. Tilgjengelig fra: https://brage.bibsys.no/xmlui/handle/11250/280127 (nedlastet 20.02.2018).

14. Hatlevik I, et al. Utdanningskvalitet i sykepleierutdanningene ved Høgskolen i Oslo og Akershus. Oslo: Senter for profesjonsstudier, Høgskolen i Oslo og Akershus; 2015.

15. Bjerknes M, Christiansen B. Praksisveiledning med sykepleierstudenter. Oslo: Gyldendal Akademisk; 2015.

16. Norsk Sykepleierforbund. Politisk plattform for sykepleierutdanning 2017-2020. Oslo: Norsk Sykepleierforbund; 2017. 